\title{
Study on Training of Computer Science and Technology
} of College Students

\author{
Zhiqiang Zhao ${ }^{1, \text { a }}$,Yan $\mathrm{Gao}^{1, \mathrm{~b}}$,Shengxiao $\mathrm{Li}^{2, \mathrm{c}}$ \\ ${ }^{1}$ Section of Recruitment and Employment, Shenyang Jianzhu University, Shenyang,
} 110168, China P.R.

\author{
${ }^{2}$ Architectural Design and Research Institute, Shenyang Jianzhu University, Shenyang, 110168, \\ China P.R. \\ a5920684@qq.com, bjyb@sjzu.edu.cn, clishengxiao@163.com
}

\begin{abstract}
Keywords: science, technology, countermeasures
Abstract. Now days, Computer science and technology program is not only one of the required programs in the modern colleges and universities, but also necessary knowledge and skill that are required by the information age on talented personnel to possess. At present, seen from the teaching activities and training situation of computer science and technology in Chinese colleges and universities, some progresses have been made, but there is still a greater development space for it. In this paper, some suggestions are proposed by the author on the training of the computer science and technology personnel in colleges and universities, only for the academic exchange.
\end{abstract}

\section{Introduction}

In recent years, more and more students choose to study computer science and in recent years, more and more students choose to study computer science and technology. With the increasing of the number of graduates, the college students are going to go to the unknown society from the ivory tower they have lived for more than ten years, and strive for the expectations from themselves, their parents and the society. In broad terms, at all times and in all over the world, all the college students are walking on the way to work. After graduating from university and go to work, they should find a job and be a professional whether specialist, undergraduate, master, doctor, and post doctor. The professional people in a very embarrassing position is different from the white-collar workers and the blue collar workers, but the dubbed collar workers which have both theoretical knowledge and operational techniques, and also have noble character and pursue. How can we make out occupation career has become the problem which all the college students are thinking about. This problem makes the college students face a lot of psychological pressure which increased with the growth of grade. It will make college students at a loss in selecting their careers if not handled appropriately. As Sun Tzu said, 'Know yourself and know your enemy, you will win every war.' It is not only the art of war on the books, but also suit for our way to find jobs, especially our college students.

\section{How to avoid these mistakes?}

First, facing these kinds of employment problems, we should have correct self-cognition and self-evaluation, know our occupation development direction, and analyze the most suitable job characteristics and geographical scope in terms of the career advancement. We have much high expectations for ourselves, but this kind of high expectations may make us to ignore some jobs so that many college students will in a state of embarrassment that we don't want to have a bad work, but cannot have a better work. Thus it can be seen that a correct self-estimate is very important. Only know your strengths and weakness can us to find a job which is really suited for you. Second, to reflect on our own school and family education deeply. For a long time, exam-oriented education in our country makes schools set their sights on the enrolment rate in the past, and parents set their sights on our scores. Many parents have implied a mind that only go to an excellent university can find a good job. But this kind of thinking makes children produce a wrong mind that so long as we go to an excellent university, we can find a good job. Meanwhile, many parents put a lot of towards 
to send their children to a key middle school, so that their children could go to a better university. Most of the key middle schools ignore the cultivation of students' willpower and mental quality for high enrolment rate. So, it will be more difficult to develop the employment psychology and skills if we put more for the ideological and policy education on our employment guidance course in university.

Therefore more and more on the training of specialists in the field of computer teaching in colleges and universities focus on guiding students to make the right career planning and improve yourself The professional knowledge. In recent years, the employment situation shows that for the future development direction have clear goals and reasonably adjust the structure of professional learning and knowledge, Can directly increase the success rate of the employment of college students . Therefore, studying computer science and technology professional college students not only to plan their future Industry development goals, and it should be adjusted according to the planning of professional learning and knowledge structure, strengthen the professional knowledge It is wrong that the employment education has nothing to do with non-graduating students. From my own perspective, the establishment of employment concept and talent training has a close relationship. The final aim is employment for students to study. No clear idea of employment, no clear learning orientation. Having employment education in advance is benefit to guide the non-graduated students especially new students to plan the life in school, make their own learning schedule, and help them to correct the study attitude, then motivate their morale to study.

Nowadays, many students of grade one or grade two have no general planning of their future career, and consider that employment is far away from them so that they are confusing about working. Even many students have no idea about what knowledge should they learn of their own major, and what certificate should they have before graduate. So, it is very benefit to help students to establish a correct view of learning and employment, and create a strong campus learning atmosphere, if we can strengthen the employment education for students, clear the professional learning requirements, inform the student social unit standards and requirements, and guide the students to scientifically choose the learning content, consciously cultivate professional skills, actively take the initiative to obtain the corresponding certificate.

In nowadays' society, many graduates cannot find a satisfactory job. In one hand, due to the limited participating quota of employers, and in other hand, many graduates cannot adapt to the development of society that their mind like stop in the past. Whether the graduates can graduate smoothly depends on whether their employment thinking can change with the development of society and adjust for it. Every graduates should obey the principle of social needs, and deal with the relationship between individual and society to make a correct employment idea. More than that, many people are not satisfied with their jobs after employment, and want to return to continue with postgraduate education or pioneer by themselves. It is not completely true that someone faced to the uneasy job in the fierce competition may be thought as self-motivated. Every post needs talents. Every profession produces its own topmost master in 360 kinds. Since we cannot make the society adapt to us, we should adapt to the society. Universities should make students have a realization that they need to have a plan about their future, and avoid a last minute rush to get things done.

For example, we should have a professional ideal firstly. Professional ideal is the pursue of future career, and it is the point cut and the key for universities to help students to have a firm professional ideal. College students' professional ideal is the spiritual support of their life career. It can promote college students to study hard, full themselves for their career needs, and obtain their career goals.

Computer aided technology, the design is for graphic design or decoration Departments, the company specialized in all kinds of computer, advertising design and manufacturing company, When the car marketing design using computer system to achieve the best effect of a kind of technology. Due to the Technical service, etc. A high degree of automation, the computer aided technology is widely used in construction, Courses include: computer application basis , computer assembly and maintenance, $\mathrm{Vi}$ sl, machinery, electronics and other fields. In the production equipment management, control and operation process $\mathrm{AB}$ is the $\mathrm{C}$ language, professional English, graphic and animation design, foundation and the computer network, computer aided technology to 
control run. At the same time in the field of teaching Local area network construction and management, development and application of the database, advertising design and making of courseware can be using the computer system for teaching, students can freely , website building and web design, multimedia design and production. From the courseware Then, we need to develop their professional skills. To help students to develop their own professional skills is the goal of vocational quality training. It is benefit for their own professional development to improve their skills. Improve skills, on one hand, is the need of social development, but on the other hand, is to prepare to get a better position and go further in the future. Corresponding skills are the capital of college students in vocational, and different professions will have different skill requirements. The understanding of skills of college students may have some vague realization that after professional study, they will have the relevant skills. To let college students understand knowledge education is the foundation of learning skills. If you want to put knowledge into skills, you must repeat practice and experience. Students have to learn to organize their own skills' list, to understand the gap between these skills and the career goals, and vocational skills training method. All of these are the problems of vocational quality education need to solve.

Finally, to make a career planning. College students should know yourself through your career plan, including understand others and society. College students should experience several practice in making planning. The first one is to collect some related in formations to improve their vocational training plan; the second one is to assess the possibility of goals when planning, and look your own ability, the limitation of environmental conditions, and the expectations of people around you; the third one is to predict the possible obstacles and how to overcome them, especially encourage students to attend some jobs in free time, in order to get more experience and social information. Through practicing, and let students have a more comprehensive understanding of themselves.

\section{Summary}

Studying computer science and technology professional college students, in the information quickly Exhibition environment to timely understand social development dynamic, and searching for the rationally Body of the profession, to the comprehensive development, and actively to improve their comprehensive quality, set up correct The outlook on life, world outlook, useful to society.We should make ourselves into a talent who can speak and write, good character, and good social communication through hard study during college. To recognize the change between school people, social people, and the role of professional people. Take the professional demand of society, personal career ideal, and good professional quality. To use the professional knowledge during the college study, and devote ourselves into the place we are going to struggle. Quickly into the society, and serve our country.

\section{Acknowledgments}

The authors would like to acknowledge the financial support of Youth Research Open Project Fund of Shenyang Jianzhu University with Grant No.2014-174.

\section{References}

[1] Mingzhong Wei: Steel Structure. Wuhan Industry University Publishers, 2000.

[2] CECS102:2002. Technical specification for steel structure of light-weight buildings with gabled frames.

[3]CEN: ENV1993-2000, Eurocode3 Design of Steel Structure (Part1.1) General rules and rules for buildings[S].

[4]Hsiao. Stress singularity effect on beam flanges in moment connections. Advances in Structural Engineering, 2005, 8(2):143-156 
[5] Haifeng Zhao, Di Jiang: ANSYS8.0 Instance Analysis of Engineering Structure .China Railway Publishers, Beijing, 2004. 